\title{
Screening for root and shoot traits in different wheat species and wild wheat relatives
}

\author{
Hayati Akman ${ }^{1 *}$, Necdet Akgun ${ }^{2}$, Ahmet Tamkoc 2
}

\section{Botamical Sciences 95 (1): 1-8, 2017}

DOI: 10.17129/botsci.747

Copyright: (C) 2017 Akman et al. This is an open access article distributed under the terms of the Creative Commons Attribution License, which permits unrestricted use, distribution, and reproduction in any medium, provided the original author and source are credited.

\section{Abstract}

Background: Definitive comparison on root traits of wheat landraces, ancient wheat species and wild wheat relatives are scarce. Those adaptive genetic resources with superior root and shoot traits can be utilized in breeding programs.

Questions: Do modern wheats have more superior root and shoot traits than ancient wheat species and wild wheat relatives?

Studied species: We performed large-scale screening for significant root and shoot traits of 47 different genotypes including cultivars, lines, landraces, ancient wheat species and wild wheat relatives belonging to 14 different species.

Study site and years: was carried out in Central Anatolian Conditions of Turkey from October, 2013 to July, 2014.

Methods: This study was conducted at $200 \mathrm{~cm}$ long tube under field weather conditions where plants can translate superior performance.

Results: A wide range of variations in terms of root and shoot traits were observed among the screened wheat cultivars, lines, landraces, ancient wheat species and wild wheat relatives. The grain yield per plant and root length per plant varied from 2.11 to $12.30 \mathrm{~g}$ and 134.7 to $250.7 \mathrm{~cm}$ in the cultivars, lines and landraces, respectively, while they ranged from 0.23 to $6.49 \mathrm{~g}$ and 170.0 to $240 \mathrm{~cm}$ in the ancient wheat species and wild wheat relatives.

Conclusions: The superior genotypes that had longer root system and high grain yield can be considered in breeding programs to improve high yielding genotypes and deep-rooted system.

Key words: Modern and ancient wheats, wild wheat relatives, root and shoot traits, screening

\footnotetext{
${ }^{1}$ Seed Department, Sarayonu Vocational School, Selcuk University, Konya, Turkey

${ }^{2}$ Field Crops Department, Faculty of Agriculture, Selcuk University, Konya, Turkey

* Corresponding author: hayatiakman@selcuk.edu.tr
} 
heat (Triticum L. spp.) is one of the world's major cereal crops, with an annual production over 713 million tons in 2013 (Faostat 2014). Throughout the world, wheat is grown from temperate, irrigated areas to dry, high-rainfall areas and warm, humid environments to dry, cold environments.

The adaptive genetic resources of wild wheats and wheat relatives, landraces, and cultivars with superior root and shoot traits can be utilized to efficiently improve the quality of wheat crops. Triticum, Aegilops, Agropyron, Haynaldia, and Secale genera possess some common characteristics (Mohibullah et al. 2011). In general, wheat landraces (Akçura 2009) and wild wheat relatives are generally tolerant to biotic and abiotic stresses. Furthermore, plant breeders consider Haynaldia villosa as a significant gene source for improving the quality of wheat grain (Vacino et al. 2010). Ancient wheats such as einkorn, emmer and Khorasan wheat all have higher contents of the carotenoid lutein than bread wheat (Shewry \& Hey 2015). The genetic diversity confers the variations in drought and salt tolerance in the wild wheats and wheat relatives (Nevo \& Chen 2010). Therefore, further studies should be performed on root and shoot traits of wheat landraces, wild wheats and wheat relatives, which contribute to increases in productivity and quality of improved crops. In addition, genetic diversity in wheat root traits was reported in bread wheat (Mackay \& Barber 1986) and durum wheat (Motzo et al. 1992).

Screening and selection for shoot and root taitrs are considered as important aspects of crop breeding programs. Screening for genotypes with deep-roots can be useful to obtain deep-rooted cultivars that take up moisture from deep soil. Deep-rooted crops rely on seasonal precipitation when water is insufficient (Sayar et al. 2007).

Traits selected in the laboratory and greenhouse may not translate to superior performance in the field. Therefore, for effective screening, the assessment should be performed under field conditions. This study aimed to screen the root and shoot traits of wheat genotypes and wild wheats and wheat relatives under field conditions.

\section{Materials and Methods}

This study screened some root and shoot traits in full grain maturity (GS 92) of 47 cultivars, lines, landraces, ancient wheat species and wild wheat relatives belonging to 14 different species under field conditions at Konya, Turkey during the 2013-2014 growing season. The soil medium consisted of a mixture of peat $(70 \%)$ and perlite $(30 \%)$. Soil samples were taken before sowing and analyzed for certain chemical and physical parameters. The soil at the experimental area has a loam texture and is slightly acidic, high in organic matter, and calcareous. It is adequate for $\mathrm{K}_{2} \mathrm{O}, \mathrm{Zn}$, and $\mathrm{Cu}$ and high for $\mathrm{Mg}$. In addition, $\mathrm{P}_{2} \mathrm{O}_{5}, \mathrm{Ca}$, and $\mathrm{Mn}$ is found in the soil as very high. The climate of the Konya can be defined as semiarid continental. According to the meteorological data, the long-term (1980-2013) and average annual rainfall (2013-2014) is 310.9 and $301.1 \mathrm{~mm}$, the average annual temperature is 10.3 and $12.5^{\circ} \mathrm{C}$, respectively.

In the study, 47 genotypes of Triticum aestivum L., Triticum Durum Desf., and Triticum compactum Host, ancient wheat species and wild wheat relatives such as Triticum spp. and Haynaldia spp. were studied (Table 1). Each genotype was sown in October toa cylindrical PVC tube that was $200 \mathrm{~cm}$ in height and $12 \mathrm{~cm}$ in diameter, which had previously been replaced to soil excavated by a backhoe (Figure 1). The tubes were established in $15 \times 15 \mathrm{~cm}$ row and intra row spaces. The experimental design was a "randomized complete block design" with three replications.

After emergence, one seedling per tube was allowed to grow. At sowing, the fertilizer DAP $\left(18 \% \mathrm{~N}, 46 \% \mathrm{P}_{2} \mathrm{O}_{5}\right) 130 \mathrm{~kg} \mathrm{ha}^{-1}$ was top-dressed on all plots. At the stem elongation stage (GS 31 ) and completing of flowering (GS 69), the plants were drip irrigated (141-tube) with a solution containing $37.5 \mathrm{~g}$ urea $(46 \% \mathrm{~N}), 64 \mathrm{~g}$ micro elements, and $11.8 \mathrm{cc}$ humic acid. The plants were watered with tap water at three times, stages of tillering, stem elongation and completion of anthesis.

At GS 92 (middle of July), the plant roots were washed and cleaned on the sieve and the longest root length was measured on a flat surface (Figure 2). In addition, number of secondary roots per plant was counted. Shoot traits such as plant height per main stem, number of fertile tillers per plant, spike length per main spike, number of spikelets per main spike, number of kernels per main spike, kernel weight per main spike and grain yield per plant were determined. 
Figure 1. PVC tubes were replaced to above $200 \mathrm{~cm}$ depth in soil under field environmental conditions

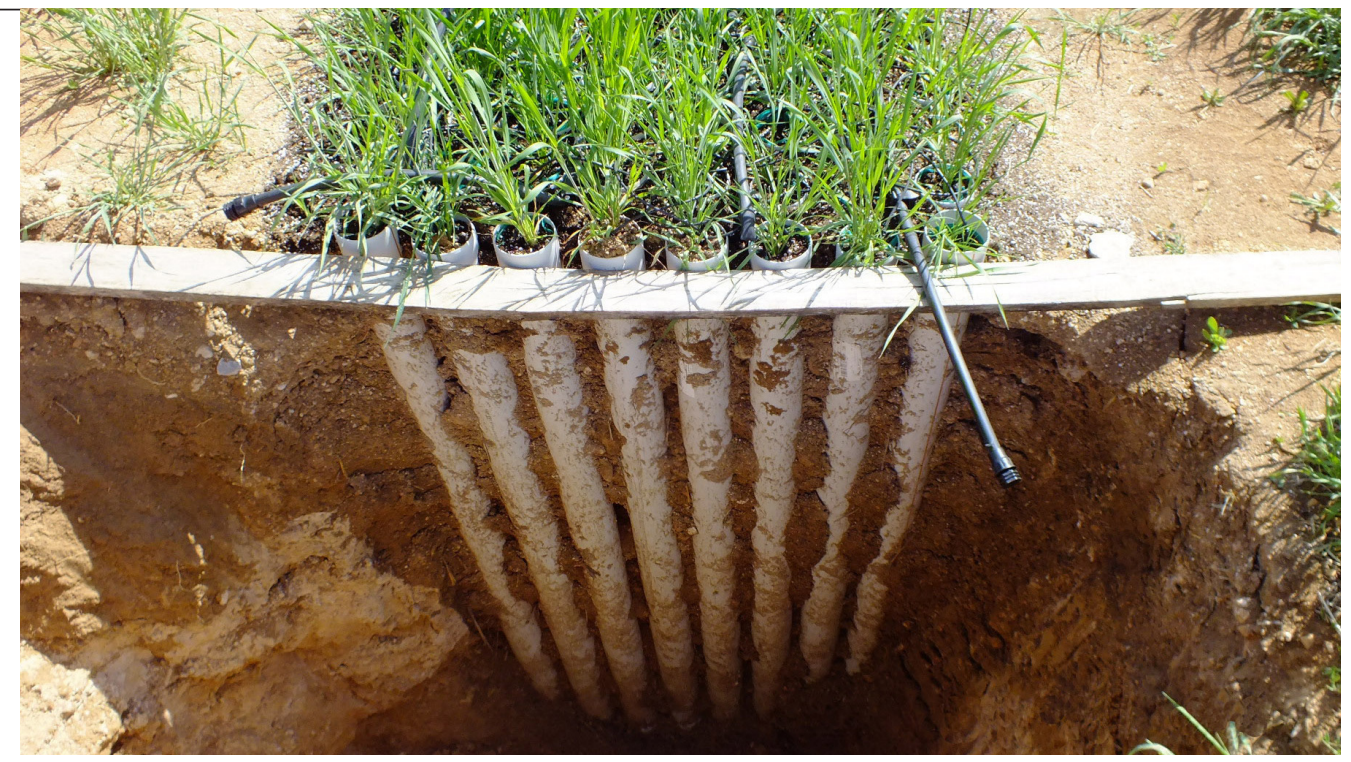

The statistical significance of the means was determined by analysis of variance using the statistical packages, MSTAT-C followed by comparisons by LSD test.

\section{Results and Discussion}

Table 2 shows the results of variance analysis related to the root and shoot traits of cultivars, lines, landraces, ancient wheat species and wild wheat relatives. The average values and groups of significance are given in Table 3. A significant difference was observed between the cultivars, lines, landraces, ancient wheat species and wild wheat relatives with regards to investigated traits $(P \leq 0.01)$.

Shoot Traits. Plant height per main stem showed differences according to the genotypes. The plant height of all the genotypes ranged from 66.7 to $148.5 \mathrm{~cm}$. The landraces, ancient wheat

Figure 2. Roots were washed on sieve after nylon bag were removed from root media

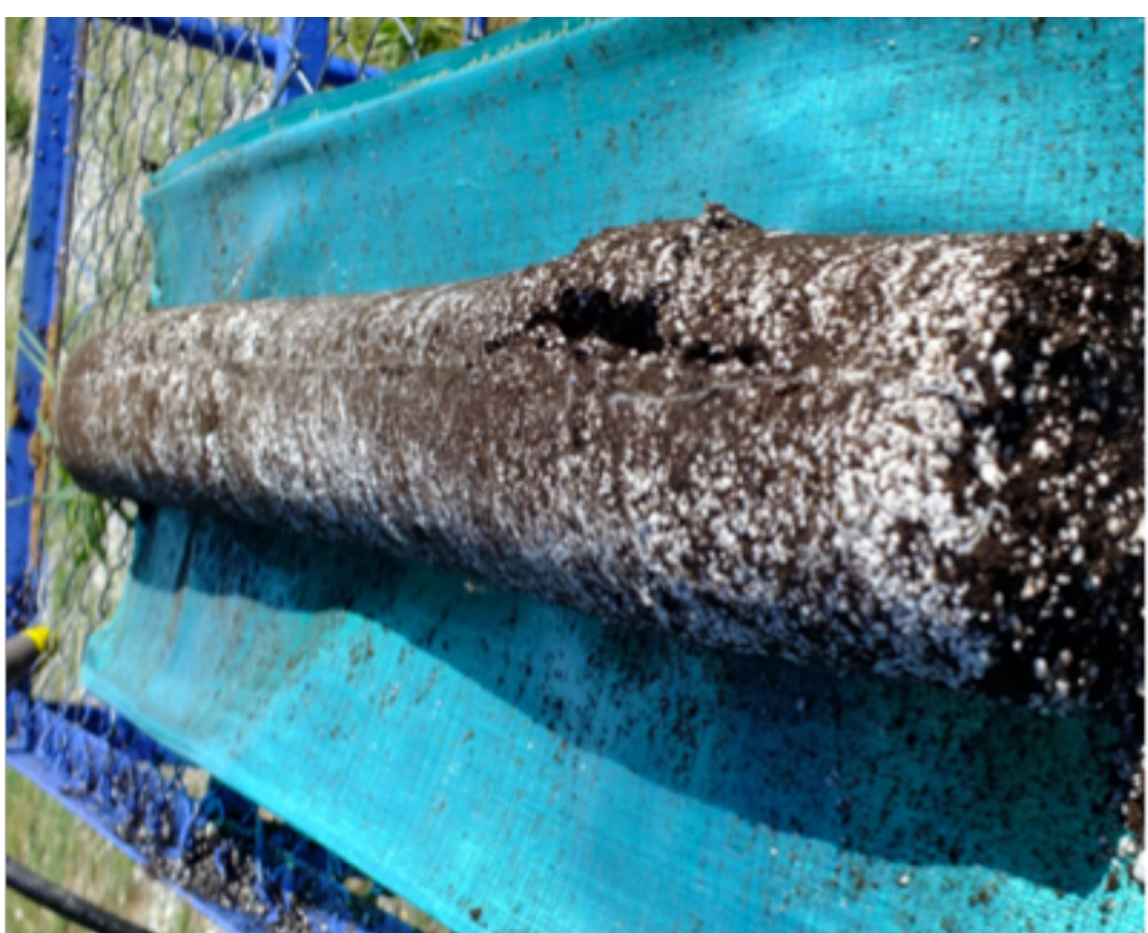


Table 1. Taxonomy and origin of modern wheats, ancient wheats and wild wheat relatives

\begin{tabular}{|c|c|c|}
\hline Genotypes & Taxonomy & Origin \\
\hline Konya 2002 & Triticum aestivum subsp. aestivum & Cultivar, Turkey \\
\hline Harmankaya & Triticum aestivum subsp. aestivum & Cultivar, Turkey \\
\hline Tosunbey & Triticum aestivum subsp. aestivum & Cultivar, Turkey \\
\hline Karahan 99 & Triticum aestivum subsp. aestivum & Cultivar, Turkey \\
\hline Ahmetağa & Triticum aestivum subsp. aestivum & Cultivar, Turkey \\
\hline Gerek 79 & Triticum aestivum subsp. aestivum & Cultivar, Turkey \\
\hline Dağdaş 94 & Triticum aestivum subsp. aestivum & Cultivar, Turkey \\
\hline Kırik & Triticum aestivum subsp. aestivum & Cultivar, Turkey \\
\hline Esperya & Triticum aestivum subsp. aestivum & Registered Cultivar, Turkey \\
\hline Kunduru 1149 & Triticum turgidum subsp. durum & Cultivar, Turkey \\
\hline Berkmen 469 & Triticum turgidum subsp. durum & Cultivar, Turkey \\
\hline TR 053 '1' & Triticum aestivum subsp. aestivum & Line, Turkey \\
\hline TR 062 & Triticum turgidum subsp. durum & Line, Turkey \\
\hline Vanlı & Triticum aestivum subsp. aestivum & Landrace, Turkey \\
\hline Kamçı & Triticum aestivum subsp. aestivum & Landrace, Turkey \\
\hline Ribasa 1 & Triticum aestivum subsp. aestivum & Landrace, Turkey \\
\hline Ribasa 2 & Triticum aestivum subsp. aestivum & Landrace, Turkey \\
\hline Gır & Triticum turgidum subsp. durum & Landrace, Turkey \\
\hline Kamut & Triticum turgidum subsp. durum & Landrace, Turkey \\
\hline AK 702 & Triticum aestivum subsp. compactum & Cultivar, Turkey \\
\hline
\end{tabular}

\begin{tabular}{|c|c|c|}
\hline \multicolumn{3}{|c|}{ Wheat genotypes from abroad } \\
\hline Yellowstone & Triticum aestivum subsp. aestivum & Cultivar, USA, Montana \\
\hline Rampart & Triticum aestivum subsp. aestivum & Cultivar, USA, Montana \\
\hline Westonia & Triticum aestivum subsp. aestivum & Cultivar, Australia \\
\hline Vizir & Triticum aestivum subsp. aestivum & Cultivar, France \\
\hline Tamaroi & Triticum turgidum subsp. durum & Cultivar, Australia \\
\hline Daws High PPO & Triticum aestivum subsp. aestivum & Near Isogenic Line, USA, Washington \\
\hline PahaNIL (vrn4) & Triticum aestivum subsp. compactum & Near Isogenic Line, USA, Washington \\
\hline \multicolumn{3}{|c|}{ Ancient wheat species and wild wheat relatives } \\
\hline Triticum turgidum (Asturie $\mathrm{H} 4$ ) & Triticum turgidum subsp. turgidum & Domesticated emmer wheat, Spain, Oviedo \\
\hline Triticum dicoccon (Rufum) & Triticum turgidum subsp. dicoccon & Domesticated emmer wheat, Ethiopia \\
\hline Haynaldia villosa & Haynaldia villosum & Wild wheat relative, Bulgaria \\
\hline Triticum turanicum (Sarı Tuya Tish) & Triticum turgidum subsp. turanicum & Khorasan wheat, Hungary, Pest \\
\hline Triticum vavilovii & Triticum vavilovii & Valilov wheat, Sweden, Uppsala \\
\hline Triticum carthlicum (Persian) & Triticum turgidum subsp. carthlicum & Persian wheat, Iran \\
\hline Aegilops biuncialis & Aegilops biuncialis & Wild relative of wheat,Turkey \\
\hline Triticum monococcum (Kelcyras) & Triticum monococcum subsp. monococcum & Domesticated einkorn, Albania \\
\hline Triticum monococcum & Triticum monococcum subsp. monococcum & Domesticated einkorn, Former Yugoslavia \\
\hline Triticum monococcum & Triticum monococcum subsp. monococcum & Domesticated einkorn, Turkey \\
\hline
\end{tabular}


Table 2. Results of variance analysis of root and shoot traits of different wheat species and wild wheat relatives

\begin{tabular}{llllllllll} 
S & DF & $\begin{array}{l}\text { Plant } \\
\text { height }\end{array}$ & $\begin{array}{l}\text { Spike } \\
\text { length }\end{array}$ & $\begin{array}{l}\text { Spikelet } \\
\text { number }\end{array}$ & $\begin{array}{l}\text { Kernel } \\
\text { number }\end{array}$ & $\begin{array}{l}\text { Kernel } \\
\text { weight }\end{array}$ & $\begin{array}{l}\text { Fertile tiller } \\
\text { number }\end{array}$ & $\begin{array}{l}\text { Grain } \\
\text { weight }\end{array}$ & $\begin{array}{l}\text { Secondary } \\
\text { root number }\end{array}$ \\
\hline R & 2 & 224.872 & 1.255 & 3.709 & 104.028 & 0.205 & 6.496 & 1.276 & 3605.645 \\
length \\
G $\quad 46$ & $1335.866^{* *}$ & $10.219^{* *}$ & $68.850^{* *}$ & $444.884^{* *}$ & $0.851^{* *}$ & $56.572^{* *}$ & $24.553^{* *}$ & $648.785^{* *}$ & $1999.373^{* *}$ \\
E $\quad 92$ & 48.316 & 0.896 & 5.285 & 61.206 & 0.080 & 4.536 & 1.540 & 334.533 & 514.350 \\
CV (\%) & 6.97 & 10.75 & 11.90 & 21.65 & 22.15 & 21.61 & 22.52 & 27.66 & 10.52 \\
\hline
\end{tabular}

${ }^{* * P} \leq 0.01$, S: Sources; R:Replication; G: Genotypes; E: Error

species and wild wheat relatives out of Aegilops biuncialis and Gir had long plant stem. The highest plant height of $148.5 \mathrm{~cm}$ was observed in two species, Triticum turgidum and Triticum boeoticum. The Australian wheat genotypes, Tamaroi $(68.3 \mathrm{~cm})$ and line 5,924 $(66.7 \mathrm{~cm})$ had the shortest plant height. Among the 222 winter wheat genotypes, the stem height varied between 110 and $133 \mathrm{~cm}$ and the most of landraces had a very long stem, however obsolete bred cultivars had a shorter stem (Dotlačil et al. 2003). Similarly, the results indicated that most of wheat landraces, ancient wheat species and wild wheat relatives had longer plant height. Cultivars originated from abroad had shorter stem height than wheat landraces, ancient wheat species and wild wheat relatives.

The spike length per main spike varied from 5.7 to $11.8 \mathrm{~cm}$ in cultivars, lines and landraces and 3.8 to $10.8 \mathrm{~cm}$ in ancient wheat species and wild wheat relatives. Similarly, it was found that spike length of Aegilops biuncialis $(3.5 \mathrm{~cm})$ was shorter than that of Triticum dicoccon $(7.3 \mathrm{~cm})$ and Triticum monococcum $(8.7 \mathrm{~cm})$ (Karagöz et al. 2006).

The number of spikelets per main spike ranged between 14.3 (Bayraktar 2000) and 23.7 (Çeşit 1252) in cultivars, lines and landraces and 3.3 (Aegilops biuncialis) and 36.3 (Triticum monoсоссит) in ancient wheat species and wild wheat relatives. There was a considerable difference between the ancient wheat species and wild wheat relatives, and the cultivated wheat genotypes in terms of spikelet number.

The number of kernels per main spike ranged from 23.7 to 68.0 in cultivars, lines and landraces and 4.7 to 36.5 in ancient wheat species and wild wheat relatives. PhaNIL (Triticum compactum) (68.0) had maximum number of kernels, while Aegilops biuncialis (4.7) had minimum number of kernels.

The maximum and minimum kernel weight per main spike was obtained in landraces; Among the genotypes, Kamut had the maximum kernel weight (2.46 g), while Ribasa 2 had the minimum kernel weight $(0.50 \mathrm{~g})$. Among the ancient wheat species and wild wheat relatives, Aegilops biuncialis had the lowest kernel weight per main spike $(0.09 \mathrm{~g})$ and Triticum vavilovii had the highest kernel weight $(1.76 \mathrm{~g})$.

The number of tillers per plant changed from 3.7 to 17.0 in cultivars, lines and landraces and 4.7 to 30.0 in ancient wheat species and wild wheat relatives. Genotypes that had more tiller per plant were not always high yielding because the grain yield was affected by yield components such as number of spikelets, number of kernels, and kernel weight per main spike.

The grain yield per plant ranged from 2.11 to $12.30 \mathrm{~g}$ in the cultivars, lines and landraces and 0.23 to $6.49 \mathrm{~g}$ in the ancient wheat species and wild wheat relatives. In the study, Triticum aestivum genotypes, Vanlı (12.30 g), Tosunbey (9.27 g), Esperya (8.74 g) and Sönmez 2001 (8.45 g), Triticum durum genotypes, Berkmen 469 (9.44 g) and Triticum compactum genotype, AK 702 (11.68 g) had higher grain yield per plant. Triticum turgidum (5.90 g), Triticum turanicum (6.49 $\mathrm{g})$, and Triticum vavilovii $(6.30 \mathrm{~g})$ had higher grain yield among the ancient wheat species and wild wheat relatives. However, Triticum boeoticum, Triticum monococcum (Kelcyras), Triticum monococcum (982) and Aegilops biuncialis had very low grain yield.

Root traits. The secondary root number widely varied in the evaluated genotypes, ranging from 42.5 to 98.3 for wheat cultivars, lines, and landraces and from 25.3 to 86.3 for ancient wheat species and wild wheat relatives. Manske et al. (2002) observed that there are two types of root in cereals, i.e., primary and secondary roots. The primary roots are called the first root or seminal root, and the secondary roots are known adventitious root, coleoptilar root, or nodal root. The secondary roots develop from first leaf node under $1-2 \mathrm{~cm}$ of soil when the leaf of the fourth 
Table 3. Root and shoot traits of different wheat species and wild wheat relatives

\begin{tabular}{|c|c|c|c|c|c|c|c|c|c|}
\hline Genotypes & $\begin{array}{l}\text { Plant height } \\
\text { (cm) }\end{array}$ & $\begin{array}{l}\text { Spike length } \\
\text { (cm) }\end{array}$ & $\begin{array}{l}\text { Spikelet } \\
\text { / Spike }\end{array}$ & $\begin{array}{l}\text { Kernel } \\
\text { /Spike }\end{array}$ & $\begin{array}{l}\text { Kernel weight } \\
\left.\text { (g spike }^{-1}\right)\end{array}$ & $\begin{array}{l}\text { Fertile tiller/ } \\
\text { Plant }\end{array}$ & $\begin{array}{l}\text { Grain yield } \\
\left.\text { (g plant }^{-1}\right)\end{array}$ & $\begin{array}{l}\text { Secondary } \\
\text { root /Plant }\end{array}$ & $\begin{array}{l}\text { Root length } \\
(\mathrm{cm})\end{array}$ \\
\hline Konya 2002 & 85.0o-u & 11.5ab & 20.0c-i & 43.0b-j & $2.05 \mathrm{ab}$ & $7.0 \mathrm{i}-\mathrm{n}$ & $7.11 \mathrm{c}-\mathrm{j}$ & 65.7a-e & 231.3a-f \\
\hline Harmankaya & $78.0 q-w$ & $9.7 \mathrm{~b}-\mathrm{h}$ & 20.7c-h & $53.3 a-d$ & $1.89 a-d$ & $7.0 \mathrm{i}-\mathrm{n}$ & $5.63 f-m$ & $97.7 \mathrm{ab}$ & 218.0a-g \\
\hline Tosunbey & 87.0n-s & $9.5 b-i$ & $17.3 \mathrm{f}-\mathrm{k}$ & 49.0b-f & $1.84 \mathrm{~b}-\mathrm{e}$ & $10.0 f-k$ & $9.27 \mathrm{bc}$ & $62.3 a-f$ & $183.7 f-i$ \\
\hline Ahmetağa & $84.7 \mathrm{o}-\mathrm{u}$ & $10.8 a-d$ & 22.0c-f & 47.0b-g & $1.59 b-k$ & $8.7 \mathrm{f}-\mathrm{I}$ & $7.73 \mathrm{c}-\mathrm{g}$ & $98.3 \mathrm{a}$ & 210.0a-g \\
\hline Gerek 79 & $106.7 \mathrm{~g}-\mathrm{I}$ & $9.2 \mathrm{c}-\mathrm{j}$ & $16.7 \mathrm{~g}-\mathrm{k}$ & $35.0 \mathrm{e}-1$ & $1.18 \mathrm{~g}-\mathrm{n}$ & 10.0f-k & $8.23 c-f$ & 74.7a-e & 223.7a-f \\
\hline Dağdaş 94 & 101.7i-n & $10.8 a-d$ & $19.7 \mathrm{c}-\mathrm{j}$ & $35.7 \mathrm{e}-\mathrm{I}$ & $1.21 \mathrm{f}-\mathrm{m}$ & $9.0 f-I$ & $7.56 \mathrm{c}-\mathrm{g}$ & 66.3a-e & 227.3a-f \\
\hline Kırik & $117.5 c-h$ & $10.8 a-d$ & $16.5 \mathrm{~g}-\mathrm{k}$ & $27.0 \mathrm{j}-\mathrm{O}$ & $1.18 \mathrm{~g}-\mathrm{n}$ & $17.0 \mathrm{bc}$ & $7.36 \mathrm{c}-\mathrm{h}$ & $42.5 \mathrm{ef}$ & 229.0a-f \\
\hline Esperya & 71.0u-w & $8.3 \mathrm{f}-\mathrm{I}$ & $20.3 c-i$ & $43.7 b-j$ & $1.54 \mathrm{~b}-\mathrm{I}$ & $9.7 \mathrm{f}-\mathrm{k}$ & $8.74 \mathrm{~cd}$ & 76.7a-e & 229.3a-f \\
\hline Kunduru 1149 & 109.0f-j & $7.2 \mathrm{j}-\mathrm{n}$ & 19.0d-k & $34.7 \mathrm{e}-\mathrm{I}$ & $1.68 b-i$ & $7.0 \mathrm{i}-\mathrm{n}$ & $4.55 j-p$ & 61.0a-f & 216.7a-g \\
\hline Berkmen 469 & $122.7 b-f$ & $6.8 \mathrm{k}-\mathrm{n}$ & 18.0f-k & $35.0 \mathrm{e}-1$ & $1.15 \mathrm{~h}-\mathrm{n}$ & $12.0 d-g$ & $9.44 \mathrm{bc}$ & 67.0a-e & $234.7 a-g$ \\
\hline TR 053 '1' & 101.7i-n & $10.8 a-d$ & $20.3 c-i$ & $44.7 b-i$ & $1.60 b-j$ & $6.7 \mathrm{i}-\mathrm{n}$ & $5.44 g-n$ & 76.3a-e & $227.0 a-f$ \\
\hline TR 062 & $115.0 c-i$ & $8.5 \mathrm{e}-\mathrm{I}$ & 16.0h-k & $33.5 f-I$ & $1.38 \mathrm{~d}-\mathrm{m}$ & $6.0 j-n$ & $2.13 \mathrm{o}-\mathrm{s}$ & 71.0a-e & 153.0hij \\
\hline Vanlı & $116.3 \mathrm{c}-\mathrm{i}$ & 10.0a-g & $15.0 \mathrm{jk}$ & $29.3 \mathrm{i}-\mathrm{n}$ & $1.24 \mathrm{e}-\mathrm{m}$ & 13.0b-f & $12.30 \mathrm{a}$ & $52.3 c-f$ & 222.7a-f \\
\hline Kamçı & $111.3 \mathrm{~d}-\mathrm{j}$ & $6.0 \mathrm{mn}$ & $20.3 c-i$ & $39.7 \mathrm{c}-\mathrm{I}$ & $1.25 \mathrm{e}-\mathrm{m}$ & $9.3 \mathrm{f}-\mathrm{k}$ & 4.10l-p & 64.0a-f & 218.3a-g \\
\hline Ribasa 1 & $124.0 \mathrm{~b}-\mathrm{e}$ & $11.8 \mathrm{a}$ & $19.3 c-j$ & $30.3 g-m$ & $1.27 \mathrm{e}-\mathrm{m}$ & $12.7 \mathrm{c}-\mathrm{g}$ & $7.00 \mathrm{c}-\mathrm{k}$ & $84.7 a-d$ & 198.7b-h \\
\hline Ribasa 2 & $111.3 d-j$ & 10.5a-e & 18.0f-k & $24.0 \mathrm{k}-\mathrm{O}$ & $0.50 o p q$ & $12.3 \mathrm{~d}-\mathrm{g}$ & $7.62 \mathrm{c}-\mathrm{g}$ & 74.0a-e & 232.3a-f \\
\hline Gır & $71.7 \mathrm{t}-\mathrm{w}$ & $5.7 \mathrm{no}$ & $14.3 \mathrm{k}$ & 23.7l-o & $0.99 \mathrm{k}-\mathrm{O}$ & $4.7 \mathrm{Imn}$ & $2.11 p-s$ & 46.3def & $134.7 j$ \\
\hline Kamut & $106.7 \mathrm{~g}-\mathrm{I}$ & $8.2 \mathrm{~g}-\mathrm{I}$ & 16.0h-k & $43.3 b-j$ & $2.46 a$ & $3.7 n$ & $3.16 m-q$ & 42.7ef & 220.0a-f \\
\hline Tamaroi & $66.7 w$ & $6.71 \mathrm{mn}$ & $17.0 \mathrm{~g}-\mathrm{k}$ & $38.3 c-1$ & $1.18 \mathrm{~g}-\mathrm{n}$ & $4.0 \mathrm{mn}$ & $2.43 \mathrm{o}-\mathrm{s}$ & 59.0b-f & $140.7 \mathrm{ij}$ \\
\hline 5924 & $68.3 \mathrm{vw}$ & $8.5 \mathrm{e}-\mathrm{I}$ & $16.3 \mathrm{~h}-\mathrm{k}$ & $30.7 \mathrm{~g}-\mathrm{m}$ & 0.95I-o & $9.7 f-k$ & $4.79 \mathrm{~h}-\mathrm{o}$ & $60.7 a-f$ & 249.0a \\
\hline Daws High PPO & $86.00-t$ & 11.0abc & $22.0 c-f$ & $43.3 b-j$ & $1.42 \mathrm{c}-\mathrm{I}$ & $9.0 f-I$ & $3.971-p$ & $82.3 a-d$ & 226.7a-f \\
\hline PahaNIL (vrn4) & 75.0r-w & $5.8 \mathrm{mno}$ & 23.3cde & $68.0 \mathrm{a}$ & $1.88 a-d$ & $5.7 \mathrm{k}-\mathrm{n}$ & 4.27I-p & 73.0a-e & 216.3a-g \\
\hline Triticum turgidum & $148.5 a$ & $8.2 \mathrm{~g}-\mathrm{I}$ & $24.0 \mathrm{c}$ & $36.5 \mathrm{e}-1$ & $1.58 \mathrm{~b}-\mathrm{k}$ & $8.5 f-m$ & $5.90 \mathrm{e}-\mathrm{I}$ & $64.5 a-f$ & $240.0 a-d$ \\
\hline Triticum dicoccon & $114.8 \mathrm{c}-\mathrm{i}$ & $7.2 \mathrm{j}-\mathrm{n}$ & $20.7 c-h$ & $34.3 \mathrm{e}-\mathrm{I}$ & $0.80 m-p$ & $11.0 e-i$ & $2.90 n-r$ & $57.0 \mathrm{c}-\mathrm{f}$ & 194.3c-h \\
\hline Triticum macha & $109.3 e-j$ & $7.5 \mathrm{i}-\mathrm{n}$ & 20.0c-i & $35.3 \mathrm{e}-\mathrm{I}$ & $1.02 \mathrm{j}-\mathrm{O}$ & $8.7 f-I$ & $2.71 \mathrm{o}-\mathrm{s}$ & 66.7a-e & 208.7a-g \\
\hline Triticum boeoticum & $148.5 \mathrm{a}$ & $10.8 a-d$ & $31.0 b$ & 12.7nop & $0.14 q$ & $10.0 f-k$ & $0.23 \mathrm{~s}$ & 86.3abc & 216.7a-g \\
\hline Triticum spelta & $124.7 \mathrm{bcd}$ & $10.7 a-d$ & 18.0f-k & $34.0 \mathrm{e}-\mathrm{I}$ & $1.10 \mathrm{i}-\mathrm{o}$ & 11.7e-h & $4.38 \mathrm{k}-\mathrm{p}$ & $84.3 a-d$ & 225.7a-f \\
\hline Haynaldia villosa & 97.3j-o & $6.0 \mathrm{mn}$ & $15.0 \mathrm{jk}$ & $23.31-0$ & $1.22 \mathrm{f}-\mathrm{m}$ & $10.7 \mathrm{f}-\mathrm{i}$ & $3.09 m-q$ & 78.0a-e & 186.0 e-i \\
\hline Triticum turanicum & $108.7 f-k$ & $9.8 \mathrm{a}-\mathrm{h}$ & 15.7ijk & $28.0 \mathrm{i}-\mathrm{O}$ & $1.41 \mathrm{c}-\mathrm{I}$ & 9.0f-I & $6.49 \mathrm{~d}-\mathrm{I}$ & 71.7a-e & 211.0a-g \\
\hline Triticum vavilovii & 96.7j-o & 10.5a-e & $18.0 f-k$ & $40.7 b-k$ & $1.76 b-g$ & $7.3 \mathrm{~h}-\mathrm{n}$ & $6.30 \mathrm{~d}-\mathrm{I}$ & 59.3a-f & 233.0a-e \\
\hline Triticum carthlicum & $108.5 f-k$ & $9.5 b-i$ & $19.5 c-j$ & $35.0 \mathrm{e}-\mathrm{I}$ & $0.79 m-p$ & $11.0 \mathrm{e}-\mathrm{i}$ & 4.62 i-p & $50.0 c-f$ & 236.0a-d \\
\hline Aegilops biuncialis & $68.0 v-w$ & 3.80 & 3.31 & $4.7 p$ & $0.09 q$ & $30.0 a$ & 0.73 qrs & $25.3 f$ & $170.0 g-j$ \\
\hline Triticum monococcum & 136.0ab & $8.5 \mathrm{e}-1$ & $36.3 a$ & $15.0 m-p$ & $0.10 q$ & $17.3 b$ & $0.33 \mathrm{rs}$ & $57.7 \mathrm{c}-\mathrm{f}$ & $226.7 a-f$ \\
\hline Triticum monococcum & $117.7 \mathrm{c}-\mathrm{g}$ & 7.8h-m & $19.0 d-k$ & 12.3op & $0.22 \mathrm{pq}$ & 4.7lmn & $0.85 q r s$ & 41.0ef & $193.3 d-h$ \\
\hline Triticum monococcum & $129.3 \mathrm{bc}$ & $7.2 \mathrm{j}-\mathrm{n}$ & $29.7 b$ & 23.7I-o & $0.58 n-q$ & 15.3b-e & $2.310-\mathrm{s}$ & 49.0c-f & $217.7 \mathrm{a}-\mathrm{g}$ \\
\hline Mean & 99.7 & 8.8 & 19.3 & 36.2 & 1.28 & 9.9 & 5.51 & 66.1 & 215.5 \\
\hline $\operatorname{LSD}(\mathrm{P} \leq 0.01)$ & 14.9 & 2.0 & 4.9 & 16.1 & 0.60 & 4.6 & 2.67 & 39.3 & 48.7 \\
\hline
\end{tabular}


main stem appears. Pinthus (1969) showed that late cultivars have not only larger number of secondary roots than early cultivars, taking a long period between germination and heading and but they have also more tillers. To some extent, the number of roots increases in proportion to the number of tillers (Roasti 2005). However, in the study, Aegilops biuncialis had the highest tiller number among the genotypes, while it had the lowest secondary root number.

Wheat cultivars, lines, landraces, ancient wheat species and wild wheat relatives showed significant differences in terms of root length, which varied from 134.7 to $250.7 \mathrm{~cm}$ for cultivars, lines and landraces and from 170 to $240 \mathrm{~cm}$ for ancient wheat species and wild wheat relatives. A study on the drought tolerance of wild barley in the early growth stages has indicated that the most significant trait is root length, followed by shoot length and root shoot length-1 ratio (Tyagi et al. 2011). The root length of wild barley (Hordeum vulgare L. ssp. spontaneum) was up to $91 \%$ greater than the spring barley cultivar, Scarlett (Sayed 2011). The average root length of wheat cultivars, lines and landraces was $216.8 \mathrm{~cm}$, however ancient wheat species and wild wheat relatives had $212.2 \mathrm{~cm}$. Root length has been shown to reach up to $2 \mathrm{~m}$ in soil (Gregory 1976, Hoad et al. 2001, Botwright Acuña \& Wade 2012), and up to $5 \mathrm{~m}$ in sandy soil (Zhang $\&$ Hu. 2013). Here, the wheat root reached up to $2.5 \mathrm{~m}$ under favorable conditions. A landrace genotype, Gir had minimum root length, however Sönmez 2001 had the maximum. In addition, Aegilops biuncialis had the shortest root system among the wild wheats and wheat relatives. Genotypes with deeper root system may have adaptation mechanisms. Deep-rooted cultivars absorb water and nitrogen from deep soil (Smika \& Grabouski 1976). Genes controlling root length may become drought tolerant by avoiding or delaying the drought effects (Ober 2008). The results of study indicated that among the cultivars, lines and landraces, Sönmez 2001, line 5924, AK 702 and ARS Amber that had a root length of $240.0 \mathrm{~cm}$ and above can be used in breeding programs to obtain deep-rooted genotypes. Triticum turgidum and Triticum vavilovii that had higher grain yield and longer root length comparing to ancient wheat species and wild wheat relatives can be considered to improve superior cultivars.

\section{Conclusions}

The evaluated cultivars, lines, landraces, ancient wheat species and wild wheat relatives showed wide range of genetic variation in terms of root and shoot traits. The average root length of wheat cultivars, lines and landraces was $216.8 \mathrm{~cm}$, while that of wild wheats and wheat relatives was $212.2 \mathrm{~cm}$. In the study, Sönmez 2001, Bezostaja 1, 5924 (line), AK 702, ARS Amber and Triticum turgidum that had up to $240.0 \mathrm{~cm}$ root length could be considered in breeding programs to improve deep rooted genotypes.

The study showed that ancient wheat species and wild wheat relatives such as Triticum monococcum, Triticum boeoticum and Haynaldia villosa resulted lower grain yield than other genotypes. However, the ancient wheat species and wild wheat relatives are known to be the most important sources of genetic wealth, providing resistance to biotic and abiotic stresses. Furthermore, Triticum vavilovii and Triticum turgidum that had higher root length and grain yield among the ancient wheat species and wild wheat relatives can be evaluated in breeding programs to improve the genotypes with high yield and deep-root system. Among the cultivars, lines and landraces, Sönmez 2001, Bezostaja1, AK 702, ARS Amber, and line 5964 that had longer root system can be considered to improve deep-rooted genotypes. In addition to deeprooting system of genotypes, more study should be performed at field conditions where plants are compared with grain yield in large plots.

\section{Acknowledgements}

The authors would like to thank Selcuk University Scientific Research Projects Coordinator for the financial support of this study under the grant No 13401004. The data presented in this article was generated in the purview of the afore-mentioned project; however, the authors of this article are only responsible for the results and discussions made here in. Authors would like to thank Prof. Dr. Ali Topal to provide TR 053 '1', TR 062 wheat lines and landraces, Prof. Dr. Phil Bruckner for Montana cultivars and USDA-ARS for genotypes from abroad. 
Received:

February 23rd, 2016

Accepted:

August 4th, 2016

\section{Literature cited}

Akçura M. 2009. Genetic variability and interrelationship among grain yield and some quality traits in Turkish winter durum wheat landraces, Turkish Journal of Agriculture and Forestry, 33: 547-556. DOI:10.3906/tar-0903-5

Gregory PJ. 1976. The growth and activity of wheat root systems. Unpubl. Ph.D. Thesis, University of Nottingham.

Botwright Acuña TL, Wade RJ. 2012. Genotype $\times$ environment interactions for root depth of wheat. Field Crops Research 137: 117-125. DOI: 10.1016/j.fcr.2012.08.004

Dotla?il L, Hermuth J, Stehno Z. 2003. Earliness, spike productivity and protein content in European winter wheat landraces and obsolete cultivars. Plant Soil Environment 49:67-74.

FAOSTAT 2014.Accessed at: http://faostat.fao.org.

Hoad S, Russell G, Lucas ME, Bingham IJ. 2001. The management of wheat, barley and oat root systems. Advances in Agronomy 74:193-246. DOI:10.1016/S0065-2113(01)74034-5

Karagöz A, Pilanalı N, Polat T. 2006. Agro-morphological characterization of some wild wheat (Aegilops L. and Triticum L.) species. Turkish Journal of Agriculture and Forestry 30:387-398.

Mackay, AD, Barber SA. 1986. Effect of nitrogen on root growth of two corn genotypes in the field. Agronomy Journal 78:699-703. DOI: 10.2134/agronj1986.00021962007800040028x

Manske GGB, Vlek PLG. 2002. Root architecture - Wheat as o model plant. In: Waisel Y,Eshel A,Beeckman T,Kafkafi U. 2002. Plant roots: The hidden half. New York: Marcel Dekker Inc., 382- 397.

Mohibullah M, Rabbani MA, Zakiullah SJ, Amin A, Farullah G. 2011. Genetic variability and correlation analysis of bread wheat (Triticum aestivum L.) accessions. Pakistan Journal of Botany 43: 2717-2720.

Motzo R, Attene G, Deidda M. 1992. Genotypic variation in durum wheat root systems at different stages of development in a Mediterranean environment. Euphytica 66: 197-206. DOI: 10.1007/BF00025303

Nevo E, Chen G. 2010. Drought and salt tolerances in wild relatives for wheat and barley improvement. Plant, Cell and Environment 33:670-685. DOI: 10.1111/j.1365-3040.2009.02107.x

Ober ES. 2008. Breeding forimproved drought tolerance and water use efficiency. HGCAConference?Arable cropping in a changing climate. http://www.hgca.com/publications/documents/S2_3_Ober_5.pdf

Pinthus MJ. 1969. Tillering and coronal root formation in some common and durum wheat varieties. Crop Science 9: 267-272. DOI: 10.2135/cropsci1969.0011183X000900030004x

Roesti D. 2005. Bacterial community associated with the rhizosphere of wheat: interactions with arbuscular mycorrhizal fungi and selection of plant growth promoting rhizobacteria for the increase of wheat growth and soil health in Indian marginal rainfed fields.Unpubl. PhD Thesis University of Neuchâtel.

Sayar R, Khemira H, Kharrat M. 2007. Inheritance of deeper root length and grain yield in half-diallel durum wheat (Triticum durum) crosses. Annals of Applied Biology 151:213-220. DOI: 10.1111/j.17447348.2007.00168.x

Sayed M. 2011. QTL analysis for drought tolerance related to root and shoot traits in barley (Hordeum vulgare $\mathrm{L}$.). PhD Thesis,Universität Bonn.

Shewry, PR, Hey S. 2015. Do "ancient" wheat species differ from modern bread wheat in their contents of bioactive components?. Journal of Cereal Science 65: 236-243. DOI: 10.1016/j.jcs.2015.07.014

Smika DE, Grabouski PH. 1976. Anhydrous ammonia applications during fallow for winter wheat production. Agronomy Journal 68: 919-922. DOI:10.2134/agronj1976.00-021962006800060019X

Tyagi K, Park MR, Lee HJ, Lee CA, Rehman S, Steffenson B, Yun SJ. 2011. Fertile crescent region as source of drought tolerance at early stage of plant growth of wild barley (Hordeum vulgare L. ssp. spontaneum). Pakistan Journal of Botany 43: 475-486.

Vacino P, Banfi R, Corbellini M, De Pace C. 2010. Improving the wheat genetic diversity for end-use grain quality by chromatin introgression from the wild wheat relative Dasypyrum villosum. Crop Science 50:528-540. DOI: $10.2135 /$ cropsci2009.04.0179

Zhang X, Hu C. 2013. Root growth and distribution in relation to different water levels.. In: Timlin D,Ahuja LR, eds., Enhancing understanding and Quantification soil-root growth interactions, Advances in Agricultural Systems Modeling, Volume 4, Madison, USA: Published by Soil Sciences Society of America Inc. DOI: 10.2134/advagricsystmodel4.c3 